\title{
H4C5 wt Allele
}

National Cancer Institute

\section{Source}

National Cancer Institute. H4C5 wt Allele. NCI Thesaurus. Code C115987.

Human $\mathrm{H} 4 \mathrm{C} 5$ wild-type allele is located in the vicinity of $6 \mathrm{p} 22.1$ and is approximately $2 \mathrm{~kb}$ in length. This allele, which encodes histone $\mathrm{H} 4$ protein, plays a role in the modulation of chromatin structure. 